(c) American Dairy Science Association, 2007.

\title{
Dairy Powder Rehydration: Influence of Protein State, Incorporation Mode, and Agglomeration
}

\author{
C. Gaiani, ${ }^{*}$ P. Schuck, $†$ J. Scher, ${ }^{*}$ S. Desobry, ${ }^{*}$ and S. Banon ${ }^{\star 1}$ \\ *LSGA, Laboratoire de Science et Génie Alimentaires, 54505 Vandoeuvre Les Nancy Cedex, France \\ †INRA, UMR Sciences et Technologies du Lait et de l'Oeuf, 35042 Rennes, France
}

\begin{abstract}
A simplified method to study rehydration was used on different dairy powders. The method involved dispersing powder in a stirred vessel equipped with a turbidity sensor. The changes of turbidity occurring during powder rehydration highlighted the rehydration stage, and the influence of the proteins' state on rehydration was clarified. Casein powders had a quick wetting time but very slow dispersion, making the total rehydration process time-consuming. On the other hand, whey powders were found to have poor wettability but demonstrated immediate dispersion after wetting. Mixing casein ( $80 \%)$ and whey $(20 \%)$ before spray drying greatly improved rehydration time compared with casein powder; whereas mixing whey powder with casein powder at the same ratio after spray drying caused a dramatic deterioration in the rehydration properties. Moreover, agglomeration was found to significantly improve the rehydration time of whey protein powder and to slow down the rehydration time of casein powder. These opposite effects were related to the rate-controlling stage (i.e., wetting stage for whey protein and dispersion stage for casein).
\end{abstract}

Key words: rehydration, powder, protein, agglomeration

\section{INTRODUCTION}

During the last few decades, much attention has been paid to the functional properties of milk proteins (Fox and Mulvihill, 1983; Kinsella, 1984; De Wit and Klarenbeek, 1986). For industrial uses, powders should be free flowing and easy to rehydrate. Indeed, powder rehydration ability is described as an essential attribute, because most powders are dissolved before use (King, 1966; Kinsella, 1984; Cayot and Lorient, 1998). Some common concerns regarding rehydration involve different stages: wettability, which is the abil-

Received April 26, 2006.

Accepted September 19, 2006.

${ }^{1}$ Corresponding author: Sylvie.Banon@ensaia.inpl-nancy.fr ity to absorb water; sinkability, which is the ability to sink into the water; dispersibility, which is the ability to disperse into single particles throughout the water (Freudig et al., 1999); and finally, dissolution, which corresponds to the separation between molecules. Depending on powder properties, each stage can take more or less time in the rehydration process (Gaiani et al., 2005, 2006).

Different methods have been proposed to study dairy powder rehydration. Using nuclear magnetic resonance, Davenel et al. (1997) evaluated dairy powder rehydration but information about the first stage (wetting) could not be obtained. The successful use of a rheological approach has also been reported (Ennis et al., 1998; Gaiani et al., 2006). In Gaiani et al. (2006), a turbidity sensor was used for monitoring the rehydration step, as previously reported by De Wit and Klarenbeek (1986) and Gaiani et al. (2005).

To study the influence of powder protein state on the rehydration behavior, the following powders were produced: native phosphocaseinate powders (NPC), whey protein isolate powders (WPI), and a mix of whey and casein powders (NPC+WPI). The NPC+WPI powders can be seen as a relevant model of milk proteins because the mix reflects the proportions of $\mathrm{CN}$ and whey in milk (i.e., $80 \% \mathrm{CN}$ and $20 \%$ whey).

The aim of this work was to acquire a better understanding of the rehydration properties of high-protein milk powders. To achieve this goal, turbidity profiles were used to assess the rehydration properties of the powders in terms of wetting time, swelling time, and time of rehydration; the influence of powder protein state was estimated in relation to rehydration properties; and chosen technological factors (protein incorporation mode and powder agglomeration) improving the rehydration were identified.

\section{MATERIALS AND METHODS}

\section{Preparation of NPC and WPI Concentrates}

The NPC concentrate was supplied by Unité Mixte de Recherche: Sciences et technologie du lait et de l'œuf (UMR STLO, INRA, Rennes, France). Native 


\section{NPC + concentrate concentrate}

pH

TS $(\mathrm{g} / \mathrm{kg})$

TN (g/kg)

Ash (g/kg)

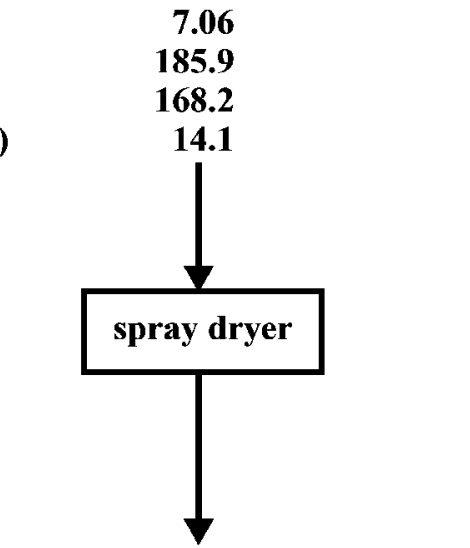

Codrying (CD) powders

A CD powder

NA CD powder
NPC concentrate

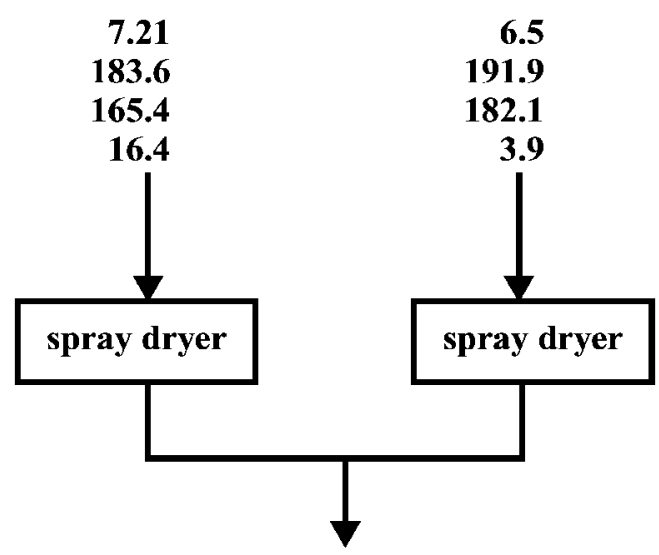

Dry-mixing (DM) powders

6.5

182.1

3.9
WPI concentrate

A DM powder
NA DM powder

Figure 1. Diagrams of the 2 incorporation modes for codrying (1) and dry mixing (2) powders. For each method, 2 types of powders were prepared: agglomerate (A) and nonagglomerate (NA) powder. The chemical properties of the concentrates were also reported. $\mathrm{CD}=\mathrm{codrying}$, $\mathrm{DM}=$ dry-mixing, $\mathrm{NPC}=$ native phosphocaseinate, $\mathrm{TN}=$ total nitrogen, $\mathrm{TS}=$ total solids, $\mathrm{WPI}=$ whey protein isolate .

phosphocaseinate was separated from skimmed milk by tangential membrane microfiltration followed by purification through water diafiltration according to Pierre et al. (1992) and Schuck et al. (1994). Whey protein isolate was obtained by membrane tangential ultrafiltration and diafiltration (4 volumes) of microfiltrate collected during NPC production with a spiral-wound organic membrane of $9.7 \mathrm{~m}^{2}$ and a cutoff close to $20 \mathrm{~kg} / \mathrm{mol}$ at a volume reduction of 20 .

\section{Powder Preparation}

The WPI and NPC concentrates were blended according to 2 methods (Figure 1): codrying (CD) and dry-mixing (DM). Mixing WPI and NPC concentrates before spray drying produced the CD powder. Mixing WPI powder with NPC powder after spray drying produced the DM powder.

The spray drying of concentrates was performed at Bionov (Rennes, France) in a 3-stage, pilot-plant spray dryer (GEA; Niro Atomizer, St Quentin en Yvelines, France) according to Schuck et al. (1998). The temperature of the concentrate before drying was $40 \pm 2^{\circ} \mathrm{C}$ for $\mathrm{NPC}$ and $20 \pm 2^{\circ} \mathrm{C}$ for WPI. The atomizer was equipped with a pressure nozzle $(0.73 \mathrm{~mm}$ diameter orifice) and a 4-slot core ( $0.51 \mathrm{~mm}$ nominal width), providing a $60^{\circ}$ spray angle. Evaporation capacity was 70 to $120 \mathrm{~kg} / \mathrm{h}$ (depending on inlet and outlet air temperature and airflow). The pressure at the nozzle was $16 \mathrm{MPa}$. Inlet temperature was at $208 \pm 5^{\circ} \mathrm{C}$ for WPI concentrate and $215 \pm 5^{\circ} \mathrm{C}$ for NPC concentrate, integrated fluid bed air temperature was $70 \pm 1^{\circ} \mathrm{C}$ for WPI and NPC concentrates, and outlet temperature was $80 \pm 1^{\circ} \mathrm{C}$ for WPI concentrate and $70 \pm 1^{\circ} \mathrm{C}$ for NPC concentrate. Inlet air humidity was controlled and adjusted by a dehumidifier (Munters, Sollentuna, Sweden). For each powder, 2 agglomerations were obtained: nonagglomerate (NA) and agglomerate (A) powders (Figure 1). The agglomerated powders were obtained by reintroduction of the fine particles after the cyclones at the head of the spray-dryer.

\section{Characterization of the Powders}

Chemical Analysis. Water content was determined by weight loss after drying $1 \mathrm{~g}$ of powder at $105^{\circ} \mathrm{C}$ for $5 \mathrm{~h}$. The total nitrogen (TN), the soluble nitrogen at $\mathrm{pH}=4.6$ (noncasein nitrogen, $\mathbf{N C N}$ ) and the $12 \%$ TCAsoluble nitrogen (NPN) were determined by Kjeldahl. Casein and whey protein contents were determined as follows: $(\mathrm{TN}-\mathrm{NCN}) \times 6.38$ and $(\mathrm{NCN}-\mathrm{NPN}) \times 6.38$, respectively. Lactose was determined by an enzymatic method using an Enzytec lactose/D-galactose kit (Diffchamb France SARL, Lyon, France) and fat according 
to the Röse-Gottlieb method (IDF, 1987). Ash was measured after incineration at $550^{\circ} \mathrm{C}$ for $5 \mathrm{~h}$.

Physical Properties. The particle size distribution was measured by static light scattering (Mastersizer S; Malvern Instruments Ltd., Malvern, UK) with a 5$\mathrm{mW} \mathrm{He}-\mathrm{Ne}$ laser operating at a wavelength of 632.8 $\mathrm{nm}$ with a $300 \mathrm{~F}$ lens. The distribution was determined using a dry powder feeder attachment and the standard optical model presentation for particles dispersed in air was used. Bulk and packed densities were measured with a powder tester (Hosokawa Micron, Osaka, Japan). Scanning electron microscopy (SEM) was performed on samples mounted on double-sided adhesive tape and attached to SEM stubs. Samples were then covered with gold by sputtering. The samples were finally examined with a Hitachi SEM instrument (Hitachi S2500; Hitachi Science Systems Ltd., Ibaraki, Japan) operated at $10 \mathrm{kV}$.

\section{Rehydration Study}

A rehydration method was developed and described in detail by Gaiani et al. (2005). Briefly, this method allowed the continuous monitoring of rehydration of dairy powders; the results obtained were found to be in agreement with standard methods (IDF, 1985; ADPI, 2002). The experiments were carried out using a protein concentration of $5 \%$ in a 2 -L vessel equipped with an impeller rotating at $400 \mathrm{rpm}$. The temperature was maintained at $24^{\circ} \mathrm{C}$ and the turbidity sensor was positioned through the vessel wall to avoid disturbances during stirring.

\section{Static Light Scattering}

From the rehydration vessel, $0.5 \mathrm{~mL}$ of NPC suspension was taken and introduced into $100 \mathrm{~mL}$ of prefiltered distilled water (Millipore France, Molsheim, France; membrane diameter $0.22 \mu \mathrm{m}$ ) to reach the correct obscuration. The Malvern small volume sample cell used allowed us to maintain a stable suspension during the measurement under stirring at 2,000 rpm. The refractive indices used were 1.57 for casein and 1.33 for water (Strawbridge et al., 1995). We calculated the average diameters from the Mie theory. The criterion selected was the $d(50)$, which means that $50 \%$ of the particles have a diameter lower than this criterion. Results are the average of triplicate experiments carried out on different days.

\section{Statistical Analyses}

Statistical analyses were carried out by using the software KyPlot version 2.0 (Koichi Yoshioka, Depart- ment of Biochemistry and Biophysics, Graduate School of Allied Health Sciences, Tokyo, Japan). For comparisons between rehydration of NPC powder and other powders (i.e., WPI, CD, and DM powders), a parametric multiple test (Dunnett test with NPC powder rehydration in water as control) was performed.

\section{RESULTS}

\section{Characterization of Powders}

The chemical composition of the powders is reported in Table 1. Native phosphocaseinate is a high-proteincontent powder with $84 \% \mathrm{CN}, 3 \%$ whey protein, and traces of fat and lactose. The colloidal minerals are collected in the ash fraction. Whey protein isolate powder is a high-whey-content powder (87\%); $\mathrm{CN}(4 \%)$ and traces of fat and lactose are also reported. In contrast with agglomerate powders, nonagglomerate powders presented slightly higher levels of moisture due to the spray drying process. The NPC and WPI were mixed to obtain $80 \% \mathrm{CN}$ and $20 \%$ whey (i.e., the protein ratio found in some milk). Consequently, a similar chemical composition was found for DM and CD powders. Traces of fat and lactose were present in all powders.

The bulked and packed densities were around 344 and $405 \mathrm{~kg} / \mathrm{m}^{3}$, respectively, for the A powders and the median size distribution of the particles was around $270 \mu \mathrm{m}$. For NA powders, the bulked and packed densities were, respectively, around 240 and $350 \mathrm{~kg} / \mathrm{m}^{3}$ and the median size distribution of the particles was around $47 \mu \mathrm{m}$. For each physical property studied, we noticed significant differences between the A and NA powders (Table 2). The A powders presented similar physical properties and different chemical compositions within the group; the same observation was made for NA powders. To study the influence of powder composition on rehydration behavior, this point was fundamental because water transfer during rehydration depends on these physical properties (density and size) (Baldwin et al., 1980; Bloore and Boag, 1982; Okos et al., 1992; Schubert, 1993).

Images from SEM of A powders are presented in Figure 2, panels A, B, and C. For NA powders, shown in panels $\mathrm{D}, \mathrm{E}$, and $\mathrm{F}$ of Figure 2, the size of the largest particles (around $50 \mu \mathrm{m}$ ) was similar to values found by static light scattering (particle size distribution in volume).

\section{NPC Powder Rehydration}

The rehydration of $5 \%$ NA NPC at $24^{\circ} \mathrm{C}$ occurred in stages as shown in Figure 3A. Dispersion of powder in the vessel led to a quick increase of turbidity (stage a). This was followed by a decrease of turbidity, with 
Table 1. Chemical composition of powders (mean of triplicate analysis)

\begin{tabular}{|c|c|c|c|c|c|c|c|}
\hline \multirow[b]{2}{*}{ Powder ${ }^{1}$} & \multirow{2}{*}{$\begin{array}{l}\text { Incorporation } \\
\text { mode }^{2}\end{array}$} & \multicolumn{6}{|c|}{ Composition (g/100 g) } \\
\hline & & $\mathrm{CN}$ & Whey & Fat & Lactose & Ash & Moisture \\
\hline A NPC & - & 83.8 & 3.1 & 0.3 & 0.4 & 7.6 & 4.8 \\
\hline A WPI & - & 4.5 & 87.1 & 0.3 & 1.3 & 2.8 & 3.9 \\
\hline $\mathrm{A}(\mathrm{NPC}+\mathrm{WPI})$ & CD & 66.4 & 21.6 & $\mathrm{ND}^{3}$ & ND & 6.9 & 4.4 \\
\hline A (NPC+WPI) & $\mathrm{DM}$ & 66.6 & 21.0 & 0.4 & 0.8 & 6.9 & 4.3 \\
\hline NA NPC & - & 83.3 & 3.4 & 0.3 & 0.4 & 7.2 & 5.4 \\
\hline NA WPI & - & 4.4 & 87.8 & 0.2 & 1.0 & 2.1 & 4.5 \\
\hline NA (NPC+WPI) & CD & 65.5 & 20.7 & ND & ND & 7.1 & 4.9 \\
\hline NA (NPC+WPI) & DM & 65.9 & 21.2 & 0.3 & 0.6 & 6.9 & 5.1 \\
\hline
\end{tabular}

${ }^{1} \mathrm{~A}=$ Agglomerate; $\mathrm{NA}=$ nonagglomerate; $\mathrm{NPC}=$ native phosphocaseinate; $\mathrm{WPI}=$ whey protein isolate.

${ }^{2} \mathrm{CD}=$ Codrying; $\mathrm{DM}=$ dry-mixing.

${ }^{3} \mathrm{ND}=$ Not determined.

a minimum recorded after about $1,000 \mathrm{~s}$ (stage b). A second increase in turbidity occurred following stage b. At the end of the profile, a homogeneous fluid was formed at around 34,000 s (stage c) and the turbidity value stabilized at 14,000 nephelometry turbidity units (NTU). The turbidity profile of 5\% A NPC followed identical stages (Figure 3B). The lengths of the stages were different, however: Stages $a$ and $b$ were shorter and stage $\mathrm{c}$ was longer. During NPC rehydration, samples were taken into the liquid vessel and the particle size was determined by static light scattering. As shown in Figure $3 \mathrm{~A}$ and B, the events observed by turbidity measurements (stages $\mathrm{b}$ and $\mathrm{c}$ ) were related to particle size variations. Dispersion of powder led to a quick increase of turbidity (stage a) due to the wetting of particles. This wetting stage was visually determined and was followed by a swelling of the particles from 46 to $54 \mu \mathrm{m}$ for NA NPC and from 286 to $386 \mu \mathrm{m}$ for A NPC. This swelling corresponded for both powders to the minimum of turbidity (stage b). As a consequence of the swelling, a disintegration of the particles and their progressive dissolution could explain the turbidity increase and particle size decrease. After $34,000 \mathrm{~s}$ of rehydration for NA NPC and $48,000 \mathrm{~s}$ of rehydration for A NPC, stable particle size (at $0.36 \mu \mathrm{m}$ ) and stable turbidity were observed, probably due to the end of rehydration (stage c).

\section{WPI Powder Rehydration}

Turbidity profiles of WPI powders during rehydration are presented in Figure 4. After powder addition the turbidity signal immediately increased from 0 to 200 NTU. An unstable turbidity signal was noted, lasting at least $1,000 \mathrm{~s}$ for NA WPI (Figure 4A) and 300 $\mathrm{s}$ for A WPI (Figure 4B). This instability was related to the wetting stage (stage a). Indeed, this stage was visually examined and corresponded to the time necessary to wet all the particles. For the 2 powders, the wetting stage was directly followed by turbidity stabilization around $250 \mathrm{NTU}$ (stage c). The end of rehydration was found at around 1,000 s for A WPI and 300 $s$ for NA WPI.

Table 2. Physical properties of powders (mean of triplicate analysis)

\begin{tabular}{|c|c|c|c|c|c|c|c|}
\hline \multirow[b]{2}{*}{ Powder ${ }^{1}$} & \multirow{2}{*}{$\begin{array}{l}\text { Incorporation } \\
\text { mode }^{2}\end{array}$} & \multicolumn{2}{|c|}{$\begin{array}{l}\text { Bulk density } \\
\left(\mathrm{kg} / \mathrm{m}^{3}\right)\end{array}$} & \multicolumn{2}{|c|}{$\begin{array}{l}\text { Packed density } \\
\qquad\left(\mathrm{kg} / \mathrm{m}^{3}\right)\end{array}$} & \multicolumn{2}{|c|}{ Size $(\mu \mathrm{m})$} \\
\hline & & Mean & SD & Mean & $\mathrm{SD}$ & Mean & SD \\
\hline A NPC & - & $340^{\mathrm{a}}$ & 4.5 & $395^{\mathrm{a}}$ & 4.0 & $285^{\mathrm{a}}$ & 3.1 \\
\hline A WPI & - & $352^{\mathrm{a}}$ & 6.4 & $405^{\mathrm{a}}$ & 3.6 & $244^{\mathrm{a}}$ & 2.8 \\
\hline A (NPC+WPI) & CD & $341^{\mathrm{a}}$ & 8.0 & $415^{\mathrm{a}}$ & 4.9 & $275^{\mathrm{a}}$ & 2.7 \\
\hline $\mathrm{A}(\mathrm{NPC}+\mathrm{WPI})$ & DM & $\mathrm{ND}^{3}$ & - & ND & - & $260^{\mathrm{a}}$ & 3.0 \\
\hline NA NPC & - & $238^{\mathrm{b}}$ & 4.7 & $329^{b}$ & 3.5 & $46.8^{\mathrm{b}}$ & 2.1 \\
\hline NA WPI & - & $235^{\mathrm{b}}$ & 5.5 & $374^{\mathrm{b}}$ & 4.1 & $44.2^{\mathrm{b}}$ & 1.9 \\
\hline NA (NPC+WPI) & $\mathrm{CD}$ & $245^{\mathrm{b}}$ & 6.8 & $354^{\mathrm{b}}$ & 4.0 & $53.2^{\mathrm{b}}$ & 3.1 \\
\hline $\mathrm{NA}(\mathrm{NPC}+\mathrm{WPI})$ & DM & ND & - & ND & - & $46.1^{b}$ & 3.3 \\
\hline
\end{tabular}

${ }^{\mathrm{a}, \mathrm{b}}$ Means with different superscript letters are different $(P<0.001)$.

${ }^{1} \mathrm{~A}=$ Agglomerate; $\mathrm{NA}=$ nonagglomerate NPC = native phosphocaseinate WPI $=$ whey protein isolate.

${ }^{2} \mathrm{CD}=$ Codrying; $\mathrm{DM}=$ dry-mixing.

${ }^{3} \mathrm{ND}=$ Not determined. 

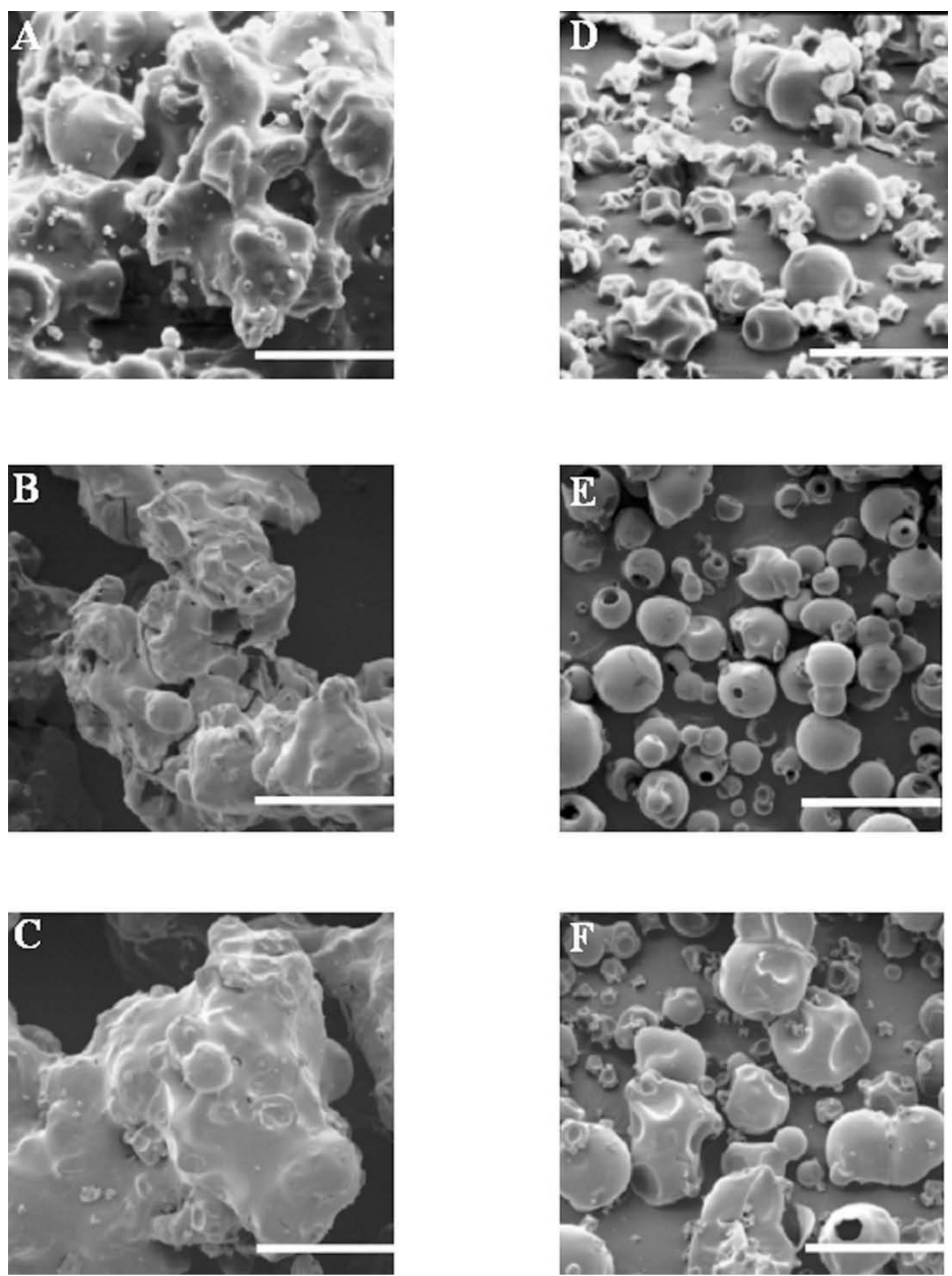

Figure 2. Scanning electron micrographs of the powders $(\times 500$, scale bar $=60 \mu \mathrm{m}) . \mathrm{A}=$ agglomerate native phosphocaseinate $(\mathrm{NPC})$; $\mathrm{B}=$ agglomerate whey protein isolate $(\mathrm{WPI}) ; \mathrm{C}=$ agglomerate codried $\mathrm{NPC}+\mathrm{WPI} ; \mathrm{D}=$ nonagglomerate $\mathrm{NPC} ; \mathrm{E}=\mathrm{nonagglomerate} \mathrm{WPI}, \mathrm{F}=$ nonagglomerate codried NPC+WPI.

\section{NPC+WPI Powder Rehydration}

Turbidity profiles during rehydration of CD powders are presented Figures 5A and B. For NA powder (Fig- ure 5A), the 3 stages were observed. Turbidity stabilization was noted around 18,000 NTU after $11,000 \mathrm{~s}$ of rehydration. For A powders (Figure 5B), the wetting and rehydration times were shorter compared with 

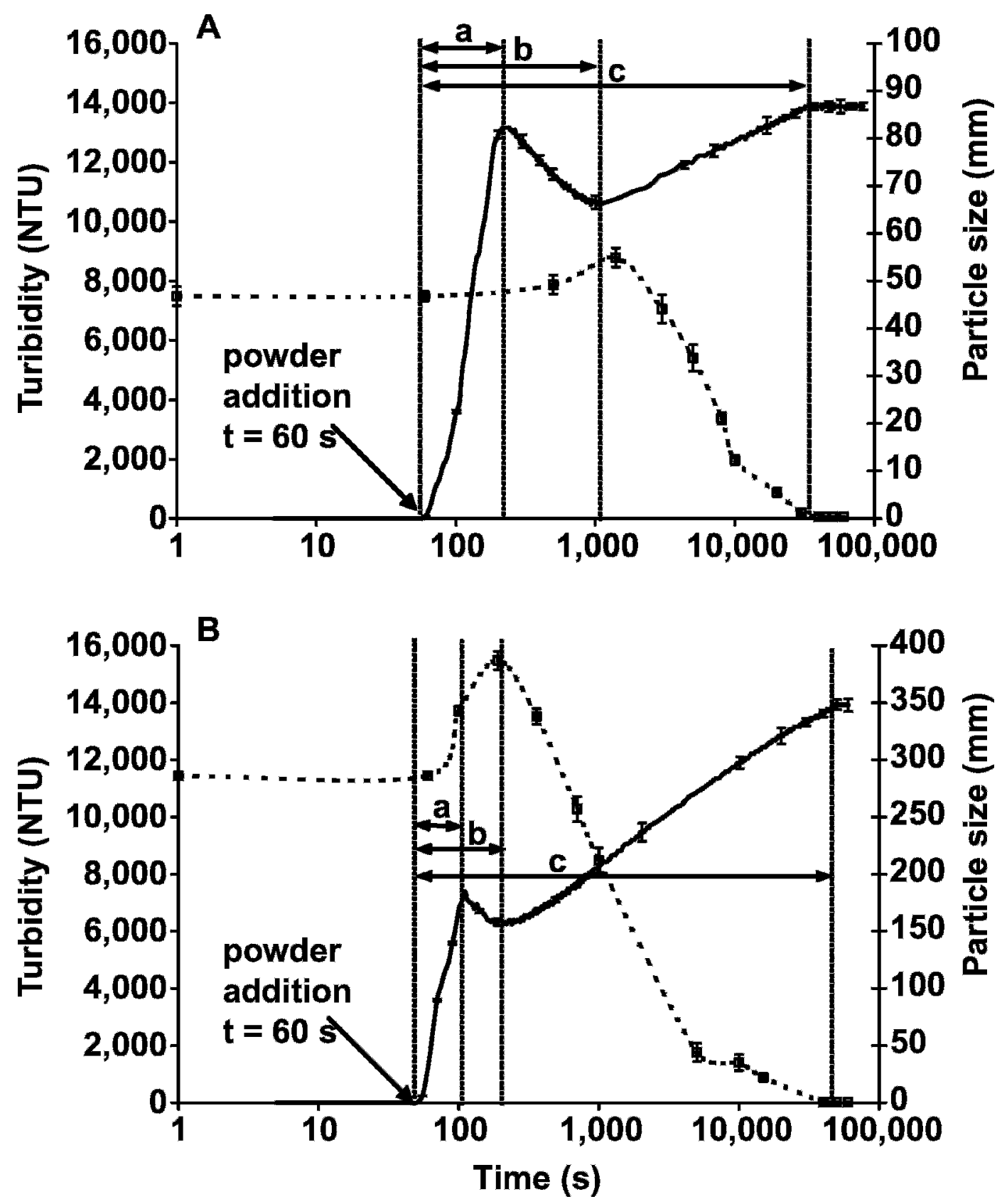

Figure 3. Typical turbidity profile (solid curve) and particle size (dotted curve) are shown as a function of log time obtained during rehydration of $5 \%$ native phosphocaseinate $(\mathrm{NPC})$ powder at $24^{\circ} \mathrm{C}$ for $80,000 \mathrm{~s} . \mathrm{A}=$ nonagglomerate $\mathrm{NPC}$ powder; $\mathrm{B}=$ agglomerate $\mathrm{NPC}$ powder; $\mathrm{a}=$ wetting time, $\mathrm{b}=$ swelling time, $\mathrm{c}=$ time to rehydrate the powder. $\mathrm{NTU}=$ nephelometry turbidity units.

those of NA powders. Turbidity stabilization was observed after $6,300 \mathrm{~s}$ and the turbidity value was still around 18,000 NTU. No turbidity decrease related to particle swelling was observed (stage b).

Turbidity profiles of DM powders are presented in Figures $5 \mathrm{C}$ and D. The wetting and swelling stages can be observed. Compared with NA powder (Figure $5 \mathrm{C}$ ), these stages were faster for A powder (Figure
5D). Turbidity stabilization (stage c) was not reached; therefore, even after $80,000 \mathrm{~s}$, the powders were not rehydrated.

\section{Rehydration Stages Obtained by Comparison with Standards}

Standards in relation to powder rehydration exist: wettability (IDF, 1985), dispersibility (IDF, 1985), and 

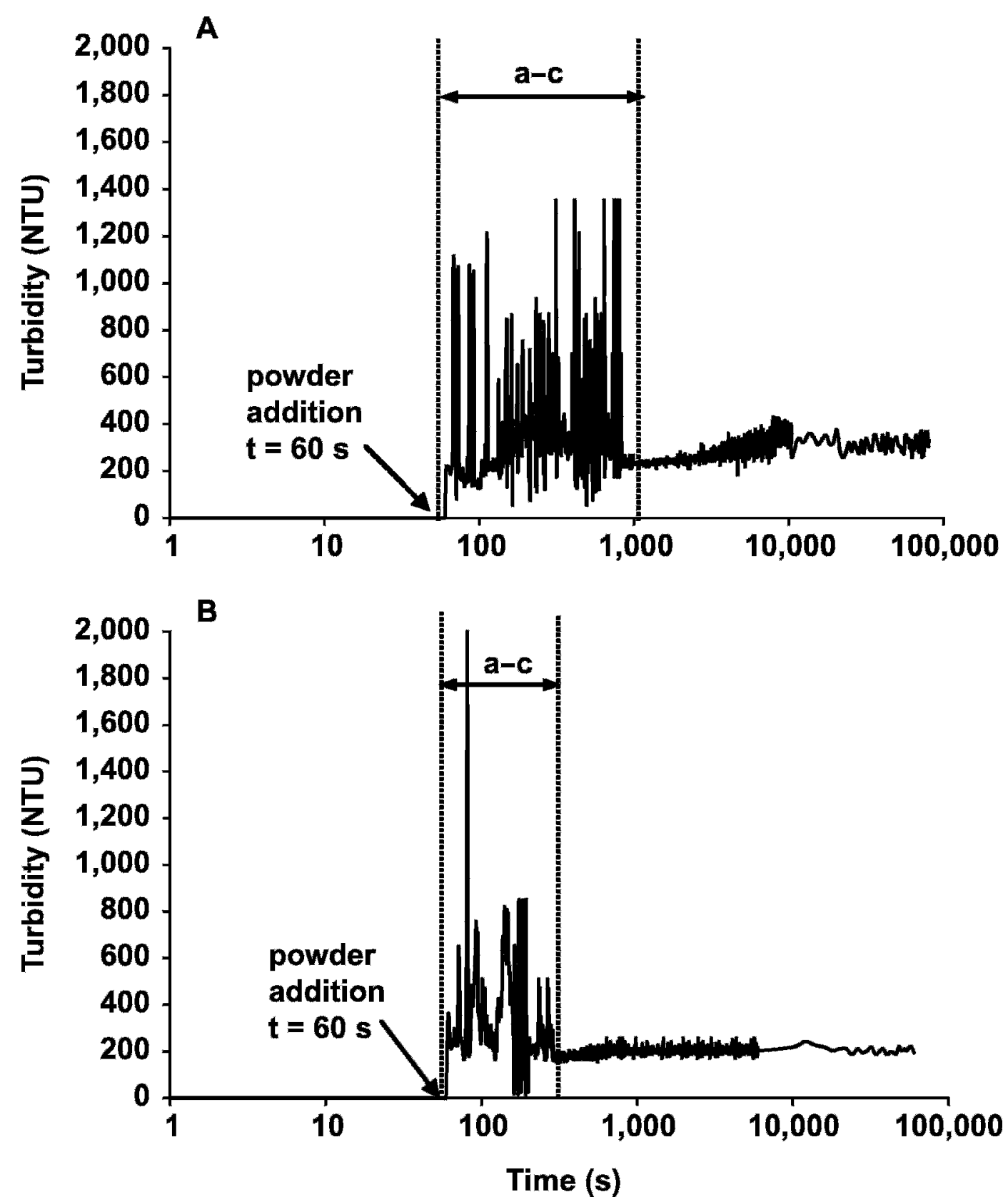

Figure 4. Turbidity profile as a function of log time during rehydration of $5 \%$ whey protein isolate (WPI) powder at $24{ }^{\circ} \mathrm{C}$ for $80,000 \mathrm{~s}$. $\mathrm{A}=$ nonagglomerate WPI powder; $\mathrm{B}=$ agglomerate WPI; $\mathrm{a}-\mathrm{c}=$ phase that includes wetting time and time to rehydrate. NTU $=$ nephelometry turbidity units.

solubility (ADPI, 2002). But these are often empirical and difficult to perform. As shown in Table 3, for A powders, the experimental wetting times obtained were always shorter than the standards due to the stirring effect, whereas the standard method was static (used no stirring). For NA powders, it was impossible to determine wettability according to the standard method. Therefore, in this study, we could not compare the 2 methods for poorly wettable powders such as NA powders. Even after a long time, the NA powders were not wetted due to the formation of a thick layer of powder between the water and surface.

A good linear relationship $\left(R^{2}>0.98\right)$ was found between the time to rehydrate the powders and the dispersibility (ADPI, 2002) as shown in Figure 6. Compared with the standard, the repeatability obtained 

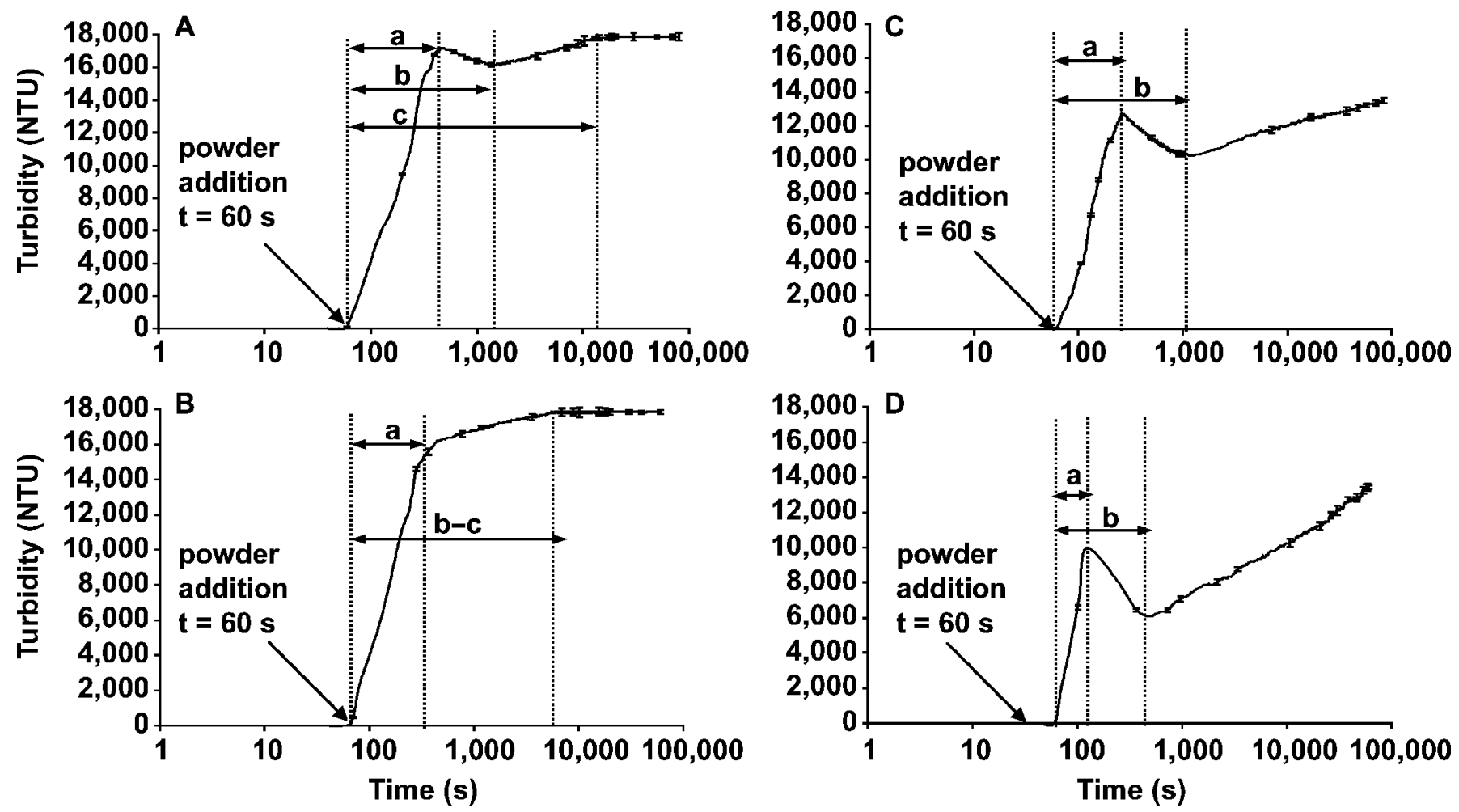

Figure 5. Turbidity profiles as a function of log time during rehydration of 5\% native phosphocaseinate + whey protein isolate (NPC+WPI) at $24^{\circ} \mathrm{C}$ for $80,000 \mathrm{~s} . \mathrm{A}=$ nonagglomerate codried powder; $\mathrm{B}=$ agglomerate codried powder; $\mathrm{C}=$ nonagglomerate dry mixed powder; $\mathrm{D}=$ agglomerate dry mixed powder; $\mathrm{a}=$ wetting time; $\mathrm{b}=$ swelling time; $\mathrm{c}=$ time to rehydrate the powder; NTU $=$ nephelometry turbidity units.

with the turbidity method was better. As expected, when a powder rehydrates easily, the dispersion percentage is higher and the time to rehydrate the powder is shorter. The same relationship was previously found by Schuck (1999) and Gaiani et al. (2005) with NPC powders enriched with soluble material.

\section{DISCUSSION}

\section{Influence of Protein State on Powder Rehydration}

Light scattering measurements allow an interpretation of the rehydration stages for $\mathrm{CN}$ powders. Therefore, it appears that rehydration of NPC occurs in different stages: wetting and swelling of the particles followed by a slow dispersion to reach a homogeneous fluid, in agreement with Gaiani et al. (2005, 2006). Using a nuclear magnetic resonance method, Davenel et al. (1997) observed 2 stages during NPC rehydration attributed to water absorption by powder and solubilization of particles (i.e., swelling and dispersion stages). They evaluated water uptake by the powder of around $5 \mathrm{~g}$ of water/g of powder during the first $20 \mathrm{~min}$ of rehydration but could not identify a wetting stage with this method.
In addition, the rehydration of whey powders was totally different compared with NPC powders (Tables 4 and 5). Because the wettability of whey powders was poor, the turbidity instability at the beginning of the profile could be due to lump formation going past the sensor (the turbidity sensor being positioned horizontally through the vessel wall) as noticed by Freudig et al. (1999). For NA WPI powder, the very long signal instability could be explained by a tendency for the lumps to be stacked together by a thick layer of wet particles due the small size of the particles (Kinsella, 1984). Powder swelling was not reported for WPI powders because globular protein powders bind less water than intact CN micelle powders (Kinsella, 1984; Robin et al., 1993). De Moor and Huyghebaert (1983) also reported that whey powders have a lower water-holding capacity than $\mathrm{CN}$ powder.

\section{Effect of Protein Incorporation Mode on Powder Rehydration}

For CD powders, the rehydration parameters were all modified compared with NPC (Tables 4 and 5). Compared with NPC, turbidity stabilization was reached 
Table 3. Wetting times obtained in our experiment in comparison with the IDF (International Dairy Federation) standard method (1987)

\begin{tabular}{|c|c|c|c|c|c|}
\hline \multirow[b]{2}{*}{ Powder $^{1}$} & \multirow{2}{*}{$\begin{array}{l}\text { Incorporation } \\
\text { mode }^{2}\end{array}$} & \multicolumn{2}{|c|}{$\begin{array}{c}\text { Standard IDF } \\
\text { wetting time }(\mathrm{s})\end{array}$} & \multicolumn{2}{|c|}{$\begin{array}{c}\text { Experimental } \\
\text { wetting time (s) }\end{array}$} \\
\hline & & Mean & SD & Mean & $\mathrm{SD}$ \\
\hline A NPC & - & 223 & 21 & 26 & 2 \\
\hline A WPI & - & 850 & 98 & 239 & 9 \\
\hline A (NPC+WPI) & CD & 580 & 50 & 206 & 7 \\
\hline $\mathrm{A}(\mathrm{NPC}+\mathrm{WPI})$ & $\mathrm{DM}$ & 323 & 55 & 63 & 2 \\
\hline NA NPC & - & $>10,000$ & - & 190 & 9 \\
\hline NA WPI & - & $>10,000$ & - & 1,009 & 27 \\
\hline NA (NPC+WPI) & CD & $>10,000$ & - & 354 & 17 \\
\hline NA (NPC+WPI) & $\mathrm{DM}$ & $>10,000$ & - & 216 & 5 \\
\hline
\end{tabular}

${ }^{1} \mathrm{~A}=$ Agglomerate $\mathrm{NA}=$ nonagglomerate NPC = native phosphocaseinate; $\mathrm{WPI}=$ whey protein isolate.

${ }^{2} \mathrm{CD}=$ Codrying; $\mathrm{DM}=$ dry-mixing.

rapidly, demonstrating that a mix of $\mathrm{CN}$ and whey favored a short rehydration. The addition of whey concentrate before spray drying could greatly improve water transfer even at low concentrations (only $20 \%$ whey). In contrast, the wetting time was significantly deteriorated $(P<0.01)$ for NA powder and $(P<0.001)$ for A powder. Even if the mix contained a majority of $\mathrm{CN}(80 \%)$, the behavior of CD powders was close to that of whey powder. Moreover, as for whey powders, no swelling stage of the A powder was observed in spite of the presence of NPC. This lack could be due to the quick rehydration, the swelling time being indis- tinguishable from the wetting time. Gaiani et al. (2005) previously demonstrated this phenomenon with NPC powders enriched in soluble material. By nuclear magnetic resonance, Davenel et al. (2002) found a significant improvement in the solubilization rate by adding $12 \%$ of whey protein to $\mathrm{CN}$ by codrying. They proposed that the steric hindrance of whey could reduce the folding of $\mathrm{CN}$ during drying, making later rehydration easier.

Rehydration time was significantly deteriorated (increased time) if the mix of proteins occurred after spray drying (Tables 4 and 5). Other authors found the same

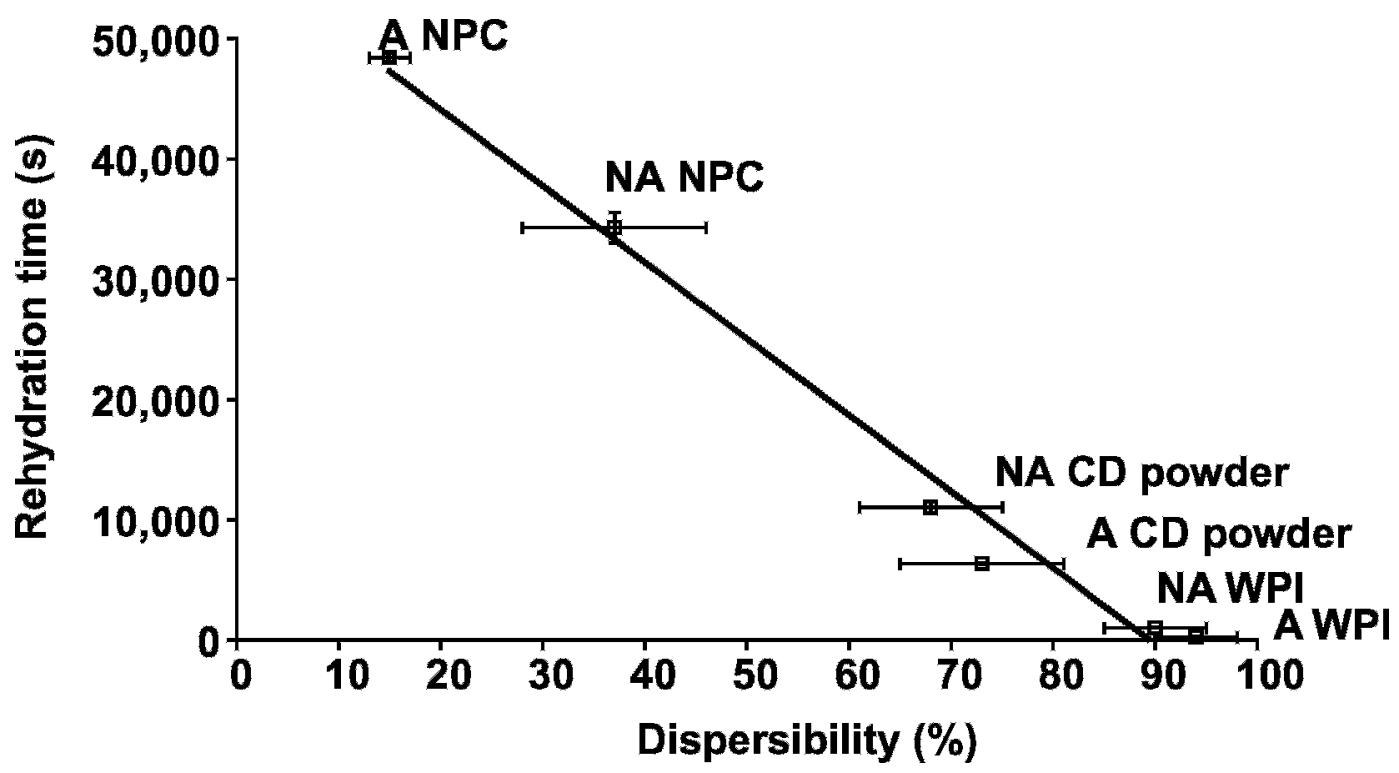

Figure 6. Relation between the dispersibility (American Dairy Products Institute standard) and the time to rehydrate the powder obtained with our experimental setup. $\mathrm{A}=$ agglomerate; $\mathrm{CD}=$ codrying; $\mathrm{DM}=$ dry-mixing; $\mathrm{NA}=$ nonagglomerate; $\mathrm{NPC}=$ native phosphocaseinate; WPI = whey protein isolate. 
Table 4. Rehydration parameters obtained for nonagglomerate powders in comparison with nonagglomerate native phosphocaseinate (triplicate analysis)

\begin{tabular}{|c|c|c|c|c|c|c|c|}
\hline \multirow[b]{3}{*}{ Powder ${ }^{1}$} & \multirow{3}{*}{$\begin{array}{l}\text { Incorporation } \\
\text { mode }^{2}\end{array}$} & \multicolumn{6}{|c|}{ Rehydration parameters ${ }^{3}$} \\
\hline & & \multicolumn{2}{|c|}{$\mathrm{Tw}(\mathrm{s})$} & \multicolumn{2}{|c|}{$\mathrm{Ts}(\mathrm{s})$} & \multicolumn{2}{|c|}{$\operatorname{Tr}(\mathrm{s})$} \\
\hline & & Mean & $\mathrm{SD}$ & Mean & $\mathrm{SD}$ & Mean & $\mathrm{SD}$ \\
\hline NA NPC & - & 190 & 9 & 1,004 & 9 & 34,293 & 1,260 \\
\hline NA WPI & - & $1,009 * * *$ & 27 & $\mathrm{NO}^{4}$ & - & 1,009 *** & 27 \\
\hline NA (NPC+WPI) & CD & $354 * *$ & 17 & $1,358 *$ & 24 & $11,023 * * *$ & 512 \\
\hline NA (NPC+WPI) & $\mathrm{DM}$ & $216^{\mathrm{NS}}$ & 5 & $1,283^{*}$ & 43 & $\mathrm{NR}^{4 * * *}$ & - \\
\hline
\end{tabular}

${ }^{1} \mathrm{NA}=$ Nonagglomerate; $\mathrm{NPC}=$ native phosphocaseinate; WPI = whey protein isolate.

${ }^{2} \mathrm{CD}=$ Codrying; $\mathrm{DM}=$ dry-mixing.

${ }^{3} \mathrm{Tw}=$ Wetting time; $\mathrm{Ts}=$ swelling time; $\mathrm{Tr}=$ rehydration time.

${ }^{4} \mathrm{NO}=$ Not observed; NR = not rehydrated after $20 \mathrm{~h}$.

$* * * P<0.001 ; * * P<0.01 ; * P<0.05 ; \mathrm{NS}=$ nonsignificant.

tendency (Davenel et al., 1997; Schuck et al., 2002). Gaiani et al. (2005) reported no positive effects for drymixing compared with codrying powders of NPC and lactose or ultrafiltrate. When samples were taken into the liquid vessel after $80,000 \mathrm{~s}$ of rehydration, the particle size, as determined by static light scattering, was polydispersed for both suspensions (A and NA DM powders). This indicated that rehydration was far from complete even after $80,000 \mathrm{~s}$ of rehydration.

\section{Agglomeration Effect on Powder Rehydration}

As expected, agglomeration had a positive effect on the wetting. The wetting time was systematically better for agglomerate particles. This consequence is well known because fast wetting is favored with large particles forming large pores. A high porosity and small contact angle between the powder surface and the penetrating powder are also ideal to obtain a quick wetting (Pisecky, 1986; Freudig et al., 1999; Gaiani et al., 2005). A surprising effect of agglomeration on time was observed. Depending on the protein state, the ag- glomeration influence involved opposite effects. Rehydration of WPI was favored for A particles, whereas NPC powder presented a quicker rehydration time for NA particles. This observation was unexpected and could be explained by the rate-controlling stage. For whey proteins, the controlling stage is the wetting (Baldwin and Sanderson, 1973; Schubert, 1993). The agglomeration improving the wetting stage, the rehydration of whey powders is favored for agglomerated particles, as the controlling stage for these powders is the wetting stage (Baldwin and Sanderson, 1973; Schubert, 1993). In contrast, the controlling stage of $\mathrm{CN}$ proteins is the dispersion. Indeed, even with a shorter wetting time, an agglomerate powder was slower to rehydrate than a nonagglomerate powder (Gaiani et al., 2005).

These results contradict those of other studies in which it was generally reported that a unique particle size of around $200 \mu \mathrm{m}$ (Neff and Morris, 1968) or 400 $\mu \mathrm{m}$ (Freudig et al., 1999) represented the optimum dispersibility and sinkability. In fact, this optimal particle size depends on the dairy powder composition. As

Table 5. Rehydration parameters obtained for agglomerate powders in comparison with agglomerate native phosphocaseinate (triplicate analysis)

\begin{tabular}{|c|c|c|c|c|c|c|c|}
\hline \multirow[b]{3}{*}{ Powder ${ }^{1}$} & \multirow{3}{*}{$\begin{array}{l}\text { Incorporation } \\
\text { mode }^{2}\end{array}$} & \multicolumn{6}{|c|}{ Rehydration parameters ${ }^{3}$} \\
\hline & & \multicolumn{2}{|c|}{$\mathrm{Tw}(\mathrm{s})$} & \multicolumn{2}{|c|}{$\mathrm{Ts}(\mathrm{s})$} & \multicolumn{2}{|c|}{$\operatorname{Tr}(\mathrm{s})$} \\
\hline & & Mean & SD & Mean & SD & Mean & $\mathrm{SD}$ \\
\hline A NPC & - & 26 & 2 & 138 & 8 & 48,436 & 337 \\
\hline A WPI & - & $239 * * *$ & 9 & $\mathrm{NO}^{4}$ & - & $239 * * *$ & 9 \\
\hline $\mathrm{A}(\mathrm{NPC}+\mathrm{WPI})$ & CD & $206 * * *$ & 7 & NO & - & $6,349 * * *$ & 88 \\
\hline $\mathrm{A}(\mathrm{NPC}+\mathrm{WPI})$ & $\mathrm{DM}$ & $63^{\mathrm{NS}}$ & 2 & $448^{* *}$ & 15 & $\mathrm{NR}^{4 * * *}$ & - \\
\hline
\end{tabular}

${ }^{1} \mathrm{~A}=$ Agglomerate NPC = native phosphocaseinate WPI = whey protein isolate.

${ }^{2} \mathrm{CD}=$ Codrying; $\mathrm{DM}=$ dry-mixing.

${ }^{3} \mathrm{Tw}=$ Wetting time; $\mathrm{Ts}=$ swelling time; $\mathrm{Tr}=$ rehydration time.

${ }^{4} \mathrm{NO}=$ Not observed; NR = not rehydrated after $20 \mathrm{~h}$.

$* * * P<0.001 ; * * P<0.01 ; * P<0.05 ; \mathrm{NS}=$ nonsignificant. 
shown in Tables 4 and 5, if dairy engineers want to optimize the time to rehydrate the powder, it seems better to rehydrate agglomerate powders if the protein is whey, and rehydrate nonagglomerate powders if the protein is $\mathrm{CN}$.

\section{CONCLUSIONS}

The industrial need for protein powders with specific properties is expanding. Because powder is the easiest way to transport and store milk derivatives, a complete understanding of the rehydration behavior of a dairy powder will become increasingly important. In this work, we evaluated the usefulness of having a reliable standardized method to determine dairy powder rehydration.

Moreover, it is essential for both dairy powder producers and users to have a method for evaluating the rehydration behavior of dairy powders. As demonstrated in this work, to optimize the rehydration of a dairy powder, dairy engineers should take into account not only technological factors such as agglomeration or the incorporation mode, but also the state of the protein to be rehydrated. In contradiction with other studies, we found that improving the wetting stage by using agglomerate powders did not systematically improve total rehydration. Depending on the protein state, to obtain quicker rehydration, it would be better to work with agglomerate (for whey) or nonagglomerate (for micellar $\mathrm{CN}$ ) powders. It is also possible to improve the rehydration properties by studying the agitation. Therefore, the influence of mixing (e.g., speed, type) on powder rehydration is currently under study.

\section{ACKNOWLEDGMENTS}

The authors are indebted to Arilait Recherches (Paris, France) for numerous stimulating discussions and financial support. Its scientific committee is gratefully acknowledged for their help to clarify some points and therefore improve the quality of the paper.

\section{REFERENCES}

ADPI. 2002. Determination of dispersibility of instant nonfat dry milk. Pages 36-38 in Standards for Grades of Dry Milks Including Methods of Analysis. American Dairy Products Institute, Elmhurst, IL.

Baldwin, A. J., A. G. Baucke, and W. B. Sanderson. 1980. The effect of concentrate viscosity on the properties of spray dried skim milk powder. N. Z. J. Dairy Sci. Technol. 15:289-297.

Baldwin, A. J., and W. B. Sanderson. 1973. Factors affecting the reconstitution properties of whole milk powder. N. Z. J. Dairy Sci. Technol. 8:92-100.

Bloore, C., and I. Boag. 1982. The effect of processing variables on spray dried milk powder. N. Z. J. Dairy Sci. Technol. 17:103-120.
Cayot, P., and D. Lorient. 1998. Les propriétés d'hydratation des protéines. Pages 209-227 in Structures et technofonctions des protéines du lait. Arilait Recherches, Tech \& Doc, Lavoisier, Paris, France.

Davenel, A., P. Schuck, and P. Marchal. 1997. A NMR relaxometry method for determining the reconstitutability and water-holding capacity of protein-rich milk powders. Milchwissenschaft 52:35-39.

Davenel, A., P. Schuck, F. Mariette, and G. Brulé. 2002. NMR relaxometry as a non-invasive tool to characterize milk powders. Lait 82:465-473.

De Moor, H., and A. Huyghebaert. 1983. Functional properties of dehydrated protein-rich milk products. Pages 276-301 in Physicochemical Aspects of Dehydrated Protein Rich Milk Products. Proc. Int. Dairy Fed. Symp., Danish Govt. Res. Inst. Dairy Ind., Helsingor, Denmark.

De Wit, J. N., and G. Klarenbeek. 1986. Method for the determination of rehydration and solubility of powdered protein-rich milk products. Milchwissenschaft 41:463-466.

Ennis, M. P., M. M. O'Sullivan, and D. M. Mulvihill. 1998. The hydration behaviour of rennet caseins in calcium chelating salt solution as determined using a rheological approach. Food Hydrocoll. 12:451-457.

Fox, P. F., and D. M. Mulvihill. 1982. Milk proteins: Molecular, colloidal and functional properties. J. Dairy Res. 49:679-693.

Freudig, B., S. Hogekamp, and H. Schubert. 1999. Dispersion of powders in liquids in a stirred vessel. Chem. Eng. Process. 38:525-532.

Gaiani, C., S. Banon, J. Scher, P. Schuck, and J. Hardy. 2005. Use of a turbidity sensor to characterize micellar casein powder rehydration: Influence of some technological effects. J. Dairy Sci. 88:2700-2706.

Gaiani, C., J. Scher, P. Schuck, J. Hardy, S. Desobry, and S. Banon. 2006. The dissolution behaviour of native phosphocaseinate as a function of concentration and temperature using a rheological approach. Int. Dairy J. 16:1427-1424.

IDF. 1987. Standard 009C: Dried milk, dried whey, dried buttermilk \& dried butter serum-Determination of fat content-RöseGottlieb reference method. International Dairy Federation, Brussels, Belgium.

IDF. 1985. Détermination de la dispersibilité et de la mouillabilité. No. V04-364. International Dairy Federation, Brussels, Belgium.

King, N. 1966. Dispersibility and reconstitutability of dried milk. Dairy Sci. Abstr. 28:105-118.

Kinsella, J. E. 1984. Milk proteins-Physicochemical and functional properties. CRC Crit. Rev. Food Sci. Nutr. 21:197-258.

Neff, E., and H. A. Morris. 1968. Agglomeration of milk powder and its influence on reconstitution properties. J. Dairy Sci. 51:330-338.

Okos, M. R., G. Narsimhan, R. K. Singh, and A. C. Weitnauer. 1992. Food dehydration. Pages 437-562 in Handbook of Food Engineering. D. R. Heldman and D. B. Lund, ed. Marcel Dekker, New York, NY.

Pierre, A., J. Fauquant, Y. le Graet, M. Piot, and J. L. Maubois. 1992. Préparation de phosphocaséinate natif par microfiltration sur membrane. Lait 72:461-474.

Pisecky, J. 1986. Standards, specifications, and test methods for dry milk products. Concentration and drying of foods. D. Mac Carthy, ed. Elsevier Applied Science, London, UK.

Robin, O., S. Turgeon, and P. Paquin. 1993. Functional proteins of milk proteins. Pages 277-353 in Dairy Science and Technology Handbook. 1. Principles and properties. VCH Publishers Inc., New York, NY.

Schubert, H. 1993. Instantization of powdered food products. Int. Chem. Eng. 33:28-45.

Schuck, P. 1999. Apprehension des mécanismes de transfert d'eau lors du séchage par atomisation de bases protéiques laitières et lors de leur réhydratation. Effet de l'environnement glucidique et mineral. $\mathrm{PhD}$ thesis. L'Ecole Nationale Supérieure Agronomique de Rennes, Rennes, France. 
Schuck, P., A. Davenel, F. Mariette, V. Briard, S. Méjean, and M. Piot. 2002. Rehydration of casein powders: Effects of added mineral salts and salt addition methods on water transfer. Int. Dairy J. 12:51-57.

Schuck, P., P. Piot, S. Méjean, J. Fauquant, G. Brulé, and J. L. Maubois. 1994. Déshydratation par atomisation de phosphocaséinate natif obtenu par microfiltration sur membrane. Lait $74: 375-388$
Schuck, P., M. Roignant, G. Brulé, S. Méjean, and J. J. Bimbenet. 1998. Caractérisation énergétique d'une tour de séchage par atomisation multiple effet. Ind. Alim. Agric. 115:9-14.

Strawbridge, K. B., E. Ray, F. R. Hallett, S. M. Tosh, and D. G. Dalgleish. 1995. Measurement of particle size distributions in milk homogenized by a microfluidizer: Estimation of populations of particles with radii less than $100 \mathrm{~nm}$. J. Colloid Interf. Sci. 171:392-398. 